\title{
Isotopic niche of the catfishes Bagre bagre and Genidens barbus in a coastal area of south-eastern Brazil
}

\author{
Ana Paula Madeira Di Beneditto ${ }^{I *}$ (), Maria Thereza Manhães Tavares $^{I} \&$ Leandro Rabello Monteiro \\ ${ }^{1}$ Universidade Estadual do Norte Fluminense, CBB, Laboratório de Ciências Ambientais, Av. Alberto Lamego, \\ 2000, CEP 28013-602, Campos dos Goytacazes, RJ, Brasil \\ *Corresponding author: Ana Paula Madeira Di Beneditto, e-mail: anapaula@uenf.br
}

DI BENEDITTO, A. P. M., TAVARES, M. T. M., MONTEIRO, L. R. Isotopic niche of the catfishes Bagre bagre and Genidens barbus in a coastal area of south-eastern Brazil. Biota Neotropica. 18(3): e20180527. http://dx.doi.org/10.1590/1676-0611-BN-2018-0527

\begin{abstract}
The isotopic niche of Bagre bagre and Genidens barbus target of commercial fisheries in a marine coastal area from northern Rio de Janeiro State $\left(\sim 21^{\circ} \mathrm{S}\right)$, south-eastern Brazil was compared to evaluate the feeding assimilation and the trophic relationship. The mean isotopic values of the catfishes and their food items in the $\delta^{13} \mathrm{C}-\delta^{15} \mathrm{~N}$ space were coherent with their respective trophic positions. The relative contributions of the food items highlighted the shrimp Xiphopenaeus kroyeri as the most assimilated item in the $\operatorname{diet}$ of B. bagre, while for G. barbus the model highlighted the fish Porichthys porosissimus. The absence of niche overlap together with the trophic evenness point to a reduced feeding overlap between B. bagre and G. barbus in northern Rio de Janeiro State. Keywords: Ariidae, feeding assimilation, stable isotopes, trophic niche, tropical area.
\end{abstract}

\section{Nicho isotópico dos bagres Bagre bagre e Genidens barbus em área costeira do sudeste do Brasil}

\begin{abstract}
Resumo: O nicho isotópico de Bagre bagre e Genidens barbus alvos de pescarias comerciais em uma área costeira marinha do norte do estado do Rio de Janeiro $\left(\sim 21^{\circ} \mathrm{S}\right)$, sudeste do Brasil, foi comparado para avaliar a assimilação alimentar e a relação trófica. Os valores isotópicos médios dos bagres e de seus itens alimentares em $\delta^{13} \mathrm{C}-\delta^{15} \mathrm{~N}$ foram coerentes com suas respectivas posições tróficas. As contribuições relativas dos itens alimentares destacaram o camarão Xiphopenaeus kroyeri como o item mais assimilado na dieta de $B$. bagre, enquanto para G. barbus o modelo destacou o peixe Porichthys porosissimus. A ausência de sobreposição de nicho juntamente com a uniformidade trófica aponta para uma sobreposição alimentar reduzida entre B. bagre e G. barbus no norte do estado do Rio de Janeiro.
\end{abstract}

Palavras-chave: área tropical, Ariidae, assimilação alimentar, isótopos estáveis, nicho trófico.

\section{Introduction}

The catfishes are Siluriformes that show a wide and complex geographic distribution throughout tropical, subtropical and temperate waters, in lagoons, rivers, estuaries and marine environment (Diogo, 2004), being an important fish group in commercial fisheries worldwide (Marceniuk 2005, Froese \& Pauly 2018). Among this primarily freshwater fish group, the family Ariidae is marine, generally more abundant in shallow coastal waters, in muddy or sandy bottoms (Marceniuk 2005, Silva et al. 2016). In general, the marine catfishes seek out river mouths and coastal lagoons during the spawning period, and they show reproductive adaptations as mouthbrooding (Chaves \& Vendel 1996, Ferraris Jr. 2007).

The marine catfishes are generalistic benthophagous feeders, consuming fishes, crustaceans, molluscs and polychaetes (Mishima \& Tanji 1982, Araújo 1984, Marceniuk et al. 2015). Tavares \& Di Beneditto
(2017) investigated the feeding habits of adult specimens of Bagre bagre (Linnaeus 1766) and Genidens barbus (Lacépède 1803) in northern Rio de Janeiro State, south-eastern Brazil. Both consumers are carnivorous with differences in feeding preference: the fish Trichiurus lepturus (Linnaeus 1758) and the shrimp Xiphopenaeus kroyeri (Heller 1862) were the most frequent prey species in the stomach contents of $B$. bagre and G. barbus, respectively. Both catfish species occur in Southwest Atlantic, being sympatric from northern to southern Brazil, where they support important resources to artisanal coastal fisheries (Froese \& Pauly 2018). The conservation status of G. barbus deserves concern along Brazilian waters, since it is considered an "endangered" species of economic interest (Portaria MMA n 445 de 17/12/2014, available at http:/www.icmbio.gov.br/portal/images/stories/biodiversidade/ fauna-brasileira/avaliacao-do-risco/PORTARIA_N\%C2\%BA_445 DE_17_DE_DEZEMBRO_DE_2014.pdf). 
Stable isotopes of nitrogen $\left(\delta^{15} \mathrm{~N}\right)$ and carbon $\left(\delta^{13} \mathrm{C}\right)$ provide data on marine vertebrates feeding ecology, understanding feeding preferences and food assimilation, and integrating diet over time (e.g. Cherel et al. 2005, Capelli et al. 2008, Di Beneditto et al. 2017, Navarro et al. 2017). The isotope values gradually increase with the trophic level, but the enrichment for $\delta^{15} \mathrm{~N}$ is more evident than for $\delta^{13} \mathrm{C}$ (Hobson \& Welch 1992, Fry 2008). The $\delta^{13} \mathrm{C}$ values, in turn, are useful to indicate the carbon sources to the diet, as aquatic vs. terrestrial, pelagic vs. benthic and inshore vs. offshore (Peterson \& Fry 1987). Isotopic models are particularly powerful when results of previous dietary studies are combined, reducing bias in data interpretation (Phillips et al. 2014). In tropical coastal areas where the availability of feeding resources is high, previous information on feeding preferences helps isotopic modelling (Di Beneditto et al. 2011).

The aim of this study is to compared the isotopic niche of adult specimens of $B$. bagre and $G$. barbus that are sympatric and target of commercial fisheries in a marine coastal area from northern Rio de Janeiro State, south-eastern Brazil, evaluating the feeding assimilation and the trophic relationship. We raised two assumptions: i) the main prey species recovered in the stomach contents are probably the most assimilated species by the consumers and ii) the isotopic niche of the consumers reflects their feeding preferences and assimilation.

\section{Materials and Methods}

\section{Sampling}

The sampling site is a marine coastal area from northern Rio de Janeiro State, southeastern Brazil $\left(\sim 21^{\circ} \mathrm{S} ; 41^{\circ} \mathrm{W}\right)$ (Figure 1). The catfishes B. bagre and G. barbus are targets of commercial gillnet fisheries practised between $21^{\circ} 35^{\prime} \mathrm{S}$ and $22^{\circ} 00^{\prime} \mathrm{S}$, from less than one to 10 nautical miles from shore, in depths varying from 10 to $30 \mathrm{~m}$. The specimens captured in these fisheries are classified as adults according to its total length: the asymptotic or maximum length recorded for $B$. bagre is $55.0 \mathrm{~cm}$ (Marceniuk et al. 2015), while for G. barbus it is 120 $\mathrm{cm}$, with the first maturity reached around $40.0 \mathrm{~cm}$ (Velasco et al. 2007 , Froese \& Pauly 2018).

In January 2016, 28 specimens of B. bagre $(50.1 \pm 4.2 \mathrm{~cm}$ of mean total length; $1,017.9 \pm 248.0 \mathrm{~g}$ of mean total weight) and 16 of $G$. barbus $(50.4 \pm 4.4 \mathrm{~cm}$ of mean total length; $1,281.3 \pm 263.9 \mathrm{~g}$ of mean total weight) were obtained from commercial fisheries. The back dorsolateral muscle samples $(5 \mathrm{~g})$ were collected for isotopic analysis.

Previous investigation about the local feeding habits of these catfishes done by Tavares \& Di Beneditto (2017) guided the prey species selection for the present study. The prey species identified in the stomach contents of $B$. bagre were the fish T. lepturus (most frequent prey), Gymnothorax ocellatus (Agassiz 1831), Paralonchurus brasiliensis (Steindachner 1875) and the shrimp X. kroyeri. For G. barbus, the prey species recorded in the stomachs were the fish Porichthys porosissimus (Cuvier 1829) and Conodon nobilis (Linnaeus 1758) and the shrimps $X$. kroyeri (most frequent prey) and Farfantepenaeus sp. Besides the prey species identified in the stomach contents (excepting G. ocellatus, C. nobilis and Farfantepenaeus sp., whose sampling was not possible), bottom-associated fish species that are common along the sampling site (Di Beneditto et al. 2001, Gomes et al. 2003) were included in the isotopic analysis as potential prey to both catfishes: Isopisthus parvipinnis (Cuvier 1830), Steliffer brasiliensis (Schultz 1945) and Symphurus plagusia (Linnaeus 1766).

The prey species (or potential prey species) were collected by local fishermen through gillnet and bottom trawl net fisheries along the sampling site (Figure 1). A sample from the back dorsolateral muscle of fish ( $5 \mathrm{~g})$ and abdomen muscle of shrimp ( $3 \mathrm{~g})$ was removed from each prey (4-6 specimens) for isotopic analysis. All samples (consumers and prey species) were kept frozen $\left(-20^{\circ} \mathrm{C}\right)$ in acid washed vials, freezedried and grounded into a fine, homogeneous powder using mortar and pestle for isotope analyses.

\section{Isotopic analysis}

Stable isotope measurements were determined on fine powdered freeze-dried samples $(1 \mathrm{mg})$ using a Delta V Advantage isotope ratio mass spectrometer (Thermo Scientific) interfaced with Conflo IV and linked to Elemental Analyzer Flash 2000 (Thermo Scientific) from the Laboratório de Ciências Ambientais - UENF. Stable isotope ratios were expressed in $\delta$ notation as parts per thousand (\%o) deviations from the international calibration standards. Pee Dee belemnite carbonate and atmospheric nitrogen were standard values for carbon and nitrogen analyses, respectively.

Quality control for muscle tissue was performed through the reference standard Elemental Microanalysis Protein Standard OAS of certified isotopic composition $\delta^{13} \mathrm{C}=-26.98 \%$ and $\delta^{15} \mathrm{~N}=5.94 \%$. Reproducibility was tested with triplicate analyses at each five samples ( $\pm 0.3 \%$ for $\delta^{15} \mathrm{~N}$ and $\pm 0.2 \%$ for $\delta^{13} \mathrm{C}$ ). Lipid content was not extracted from muscle samples prior to the analyses; however, the $\delta^{13} \mathrm{C}$ interpretation was not compromised because $\mathrm{C}: \mathrm{N}$ ratios were lower than 3.5 (low lipid levels) (Post et al. 2007).

A Bayesian approach with stable isotope mixing models in the SIAR (Stable Isotope Analysis in R) package (R Development Core Team 2016, Parnell \& Jackson 2013) estimated the relative contribution of each food item to the diet of the catfishes. This package provides the probability density distributions, mean proportion and credibility intervals for each food item, incorporating uncertainty linked to elemental concentrations, isotopic signatures and discrimination factors (Parnell et al. 2010). Isotopic mixing models can have caveats when food items with similar isotopic values are included; however, Phillips et al. (2014) argued that when results of previous dietary studies are combined with isotopic approach the models are more powerful and the bias in data interpretation is reduced. Here, the previous description about the local feeding habits of B. bagre and G. barbus guided the isotope mixing models (Tavares \& Di Beneditto 2017). Once the food items have been identified, stable isotope mixing models are consistent approaches to quantify the food assimilation (Phillips et al. 2014).

The Trophic Enrichment Factors (TEFs), or discrimination factors, are key parameters in isotopic mixing models, representing the isotopic differences between consumers' tissue and their food sources after they reached equilibrium (Parnell et al. 2010). In the absence of species-specific TEFs values from controlled diet experiments, these values can be obtained in meta-analyses for species phylogenetically related, considering the same tissue (Newsome et al. 2007). In this sense, we calculated $T E F^{15} \mathrm{~N}$ and $\mathrm{TEF}^{13} \mathrm{C}$ based on equations from a meta-analysis of isotopic studies that considered muscle of fish species 


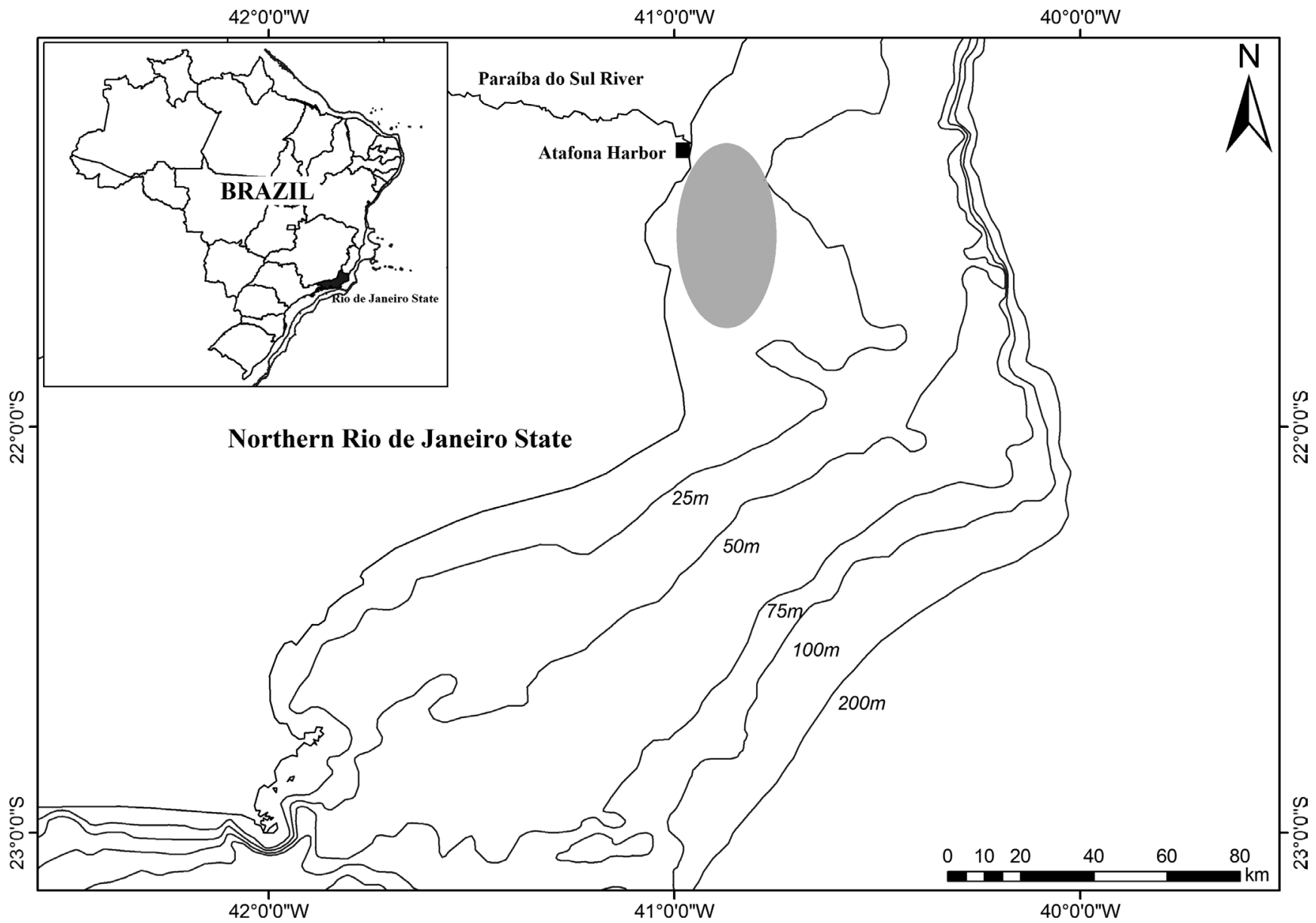

Figure 1. Map of Brazil, indicating the Rio de Janeiro State and its northern coast, where the sampling site of Bagre bagre, Genidens barbus and their prey species is located (grey ellipse).

(Caut et al. 2009) $\left(\Delta^{15} \mathrm{~N}=-0.281 \delta^{15} \mathrm{~N}+5.879\right.$ and $\Delta^{13} \mathrm{C}=-0.248 \delta^{13} \mathrm{C}$ -3.4770 ). The calculated values for our data were $+2.1 \pm 0.2 \%$ for $\mathrm{TEF}^{15} \mathrm{~N}$ and $+0.7 \pm 0.1 \%$ for $\mathrm{TEF}^{13} \mathrm{C}$.

\section{Niche width analysis}

The isotopic niche width of $B$. bagre and G. barbus was estimated by the quantitative metrics based on the position of individuals in the niche space $\left(\delta^{13} \mathrm{C} \times \delta^{15} \mathrm{~N}\right)$ (Layman et al. 2007, Jackson et al. 2011). These metrics were calculated by the functions for Stable Isotope Bayesian Ellipses in R (SIBER - Jackson et al., 2011). The Bayesian assessment for the comparison of isotopic niche metrics proposed by Jackson et al. (2011) is appropriate for small sample sizes (at least 10 samples), as in the present study ( $\mathrm{n}=28$ for B. bagre and $\mathrm{n}=16$ for G. barbus).

Five quantitative metrics derived from stable isotope data compared the trophic structure of the catfishes populations in the study area: a) $\delta^{15} \mathrm{~N}$ range (NR) that is the distance between the two individuals with the highest and lowest $\delta^{15} \mathrm{~N}$ value within a population, providing an indication of the total nitrogen range exploited by a population (a large NR might suggest omnivory); b) $\delta^{13} \mathrm{C}$ range (CR) that is the distance between the two individuals with the highest and lowest $\delta^{13} \mathrm{C}$ value within a population, providing an indication of the total carbon range exploited by a population and representing the variability of food sources consumed (a large CR implies difference in basal resources within food webs); c) Standard ellipse area (SEA) or trophic niche width, where the standard ellipse is centred on the group centroid and scaled to encompass a $40 \%$ chance $(P=0.40)$ of including a subsequently sampled datum; d) Mean distance to centroid (CD) that is the average Euclidean distance of each individual of a population to the $\delta^{15} \mathrm{~N}-\delta^{13} \mathrm{C}$ centroid for that population, used as a measure of population trophic diversity and e) Standard deviation of nearest neighbour distance (SDNND) that is the standard deviation of Euclidean distances of each individual to its nearest neighbor in the $\delta^{13} \mathrm{C}-\delta^{15} \mathrm{~N}$ scatterplot space, used to infer population trophic evenness (a low SDNND indicates a more even distribution of individuals in the trophic niche space).

The differences between the catfishes regarding mean $\delta^{15} \mathrm{~N}$ and $\delta^{13} \mathrm{C}$ values were assessed via t-tests. The SEAs of the catfishes were compared probabilistically with the posterior Bayesian distributions, calculating the proportion of ellipses for group 1 that was larger than ellipses for group 2 in the simulated draws (Jackson et al. 2011). The percent of overlapping SEA between the catfishes was the measure of isotopic niche overlap. Mean differences between species in CD were assessed by t-tests. The statistic SDNND, a standard deviation, was compared between groups by an F-ratio test. Here, the $P$ values were interpreted as strengths of evidence toward null hypotheses, rather than on the dichotomic scale of significance testing (Hurlbert \& Lombardi 2009). 


\section{Results}

Considering B. bagre and G. barbus, the mean values for $\delta^{15} \mathrm{~N}$ and $\delta^{13} \mathrm{C}$ were $+13.6 \pm 0.4 \%$ and $+12.7 \pm 0.4 \%$ o and $-16.8 \pm 0.2 \%$ and -16.9 $\pm 0.2 \%$, respectively (Figure 2 ). The comparison between the mean values indicated that differences between $\delta^{15} \mathrm{~N}\left(P=6.03^{\mathrm{e}-09}\right)$ were more significant than $\delta^{13} \mathrm{C}(P=0.07)$. The mean values for $\delta^{15} \mathrm{~N}$ in the prey species identified from the stomach contents of $B$. bagre (T. lepturus, $P$. brasiliensis, $X$. kroyeri) were lower than those found in consumer, and the same pattern was noted for the prey species of G. barbus ( $P$. porosissimus, X. kroyeri) (Figure 2).

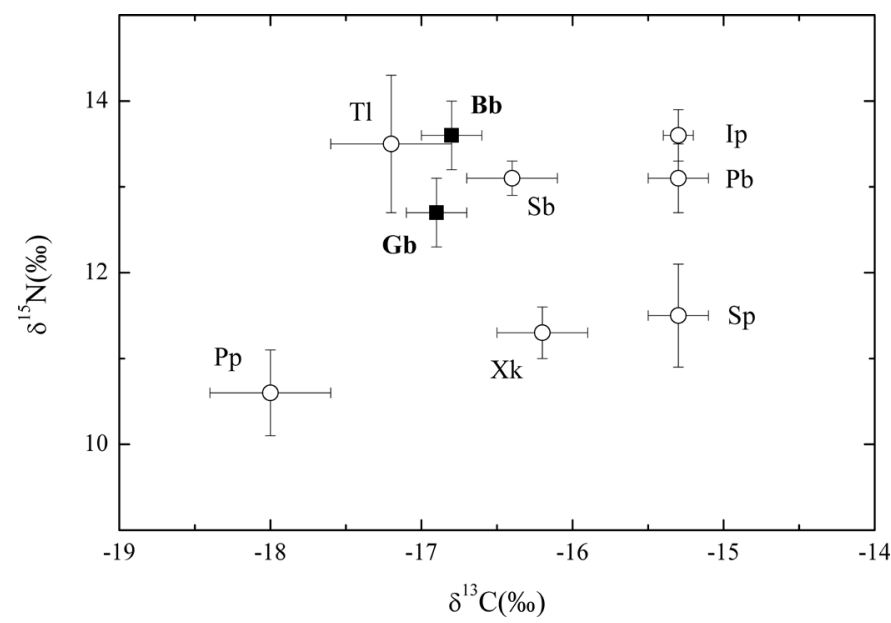

Figure 2. Relationship between $\delta^{13} \mathrm{C}$ and $\delta^{15} \mathrm{~N}$ of the catfishes Bagre bagre and Genidens barbus and their prey species. Error bars are standard deviations. $\mathrm{Bb}$ : Bagre bagre, Gb: Genidens barbus, Tl: Trichiurus lepturus, Ip: Isopisthus parvipinnis, $\mathrm{Pb}$ : Paralonchurus brasiliensis, Sb: Stellifer brasiliensis, Sp: Symphurus plagusia, Pp: Porichthys porosissimus, Xk: Xiphopenaeus kroyeri.

The Bayesian mixing model incorporated isotopic signatures of consumers and prey species, and elemental concentrations and TEFs values of prey species in the feeding assimilation analysis. The relative contributions of the prey species highlighted $X$. kroyeri as the most assimilated item in the diet of $B$. bagre, while for G. barbus the model highlighted $P$. porosissimus (Figure 3 ).

The SEAs of the catfishes were rather similar in position in the $\delta^{13} \mathrm{C}$ axis, but differences were noted in the $\delta^{15} \mathrm{~N}$ axis (Figure 4). A probabilistic comparison between the ellipse areas based on the posterior distribution of simulated ellipses indicated that $93 \%$ of the SEAs of $G$. barbus are larger than B. bagre. Moreover, no SEAs overlap was detected between the catfishes (Figure 4).

The quantitative metrics to estimate the isotopic niche width of the catfishes are presented in Table 1. Trophic preference measure ( $\delta^{15} \mathrm{~N}$ range) indicated that $B$. bagre and $G$. barbus are comparable as consumers. The species are also comparable about variability of food sources $\left(\delta^{13} \mathrm{C}\right.$ range $)$. The metric $\mathrm{CD}$ did not present a clear difference between the catfishes $(\mathrm{CD} \mathrm{t}=0.91, \mathrm{df}=33.06, P=0.37)$, indicating similarities in the trophic diversity. Meanwhile, the SDNND value of G. barbus was 3.5 times lower than the estimate for B. bagre $(\mathrm{F}=3.65$, $\mathrm{df} 1=27, \mathrm{df} 2=15, P=0.01$ ), showing a more even distribution of $G$. barbus in the trophic niche space.

\section{Discussion}

The most frequent prey species in the stomach contents of $B$. bagre and $G$. barbus were not the most assimilated species by the consumers, contradicting the first assumption of this study. Differences between ingestion and digestibility level (and assimilation) are not uncommon and can vary among different food items and consumers (Degani \& Revach 1991, Fry 2008, Pereira et al. 2012), as within individuals of the same species (Di Beneditto et al. 2017). Considering fish species, for instance, the rainbow trout Oncorhynchus mukiss (Walbaum 1792) seems to digest better red algae, whereas the Nile tilapia Oreochromis niloticus (Linnaeus 1758) does better with green and brown algae (Pereira et al. 2012). Moreover, there are bias in traditional dietary studies performed only by stomach content analysis, such as subor superestimation of prey contribution to consumer's diet, due to differences in their digestion rates (Pierce \& Boyle 1991). Regardless the relevance of these traditional studies that allow the identification of the taxonomic level of prey species (e.g., Santos et al. 2002; Di Beneditto \& Siciliano 2007; Krishnan et al. 2008), the evaluation of food items importance in the consumer's diet should take in account ingestion, digestion and assimilation rates.

The main assimilated prey by $B$. bagre ( $X$. kroyeri) is the most capture species by local shrimp fisheries (Fernandes et al. 2011, 2014), while $P$. porossissimus, the main assimilated prey by G. barbus, is bycatch in these fisheries and it is also an important prey for a coastal dolphin that inhabits the study area (Di Beneditto \& Lima 2003, Di Beneditto \& Ramos 2004). All prey species recorded in the stomach contents of these catfishes are bottom-associated resources and common year-round along the coast of northern Rio de Janeiro State (Gomes et al. 2003, Fernandes et al. 2011, Tavares \& Di Beneditto 2017). Thus, the local availability of these prey to the consumers is high.

The mean isotopic values of the catfishes and their prey species in the $\delta^{13} \mathrm{C}-\delta^{15} \mathrm{~N}$ space were coherent with their respective trophic positions; however, it might expect similar $\delta^{15} \mathrm{~N}$ values between the catfishes, instead of higher values for $B$. bagre. The $\delta^{15} \mathrm{~N}$ value has been widely considered a tool in establishing trophic levels and feeding interactions among species. Meanwhile, its efficiency as trophic marker is sensitive to consumers body size, nutritional status and excretion metabolism (Hobson et al. 1996, Jennings et al. 2002), as well as quantitative and qualitative differences in food ingestion and assimilation (Kurle \& Worthy 2001, Das et al. 2003).

All catfish specimens analysed in the present study are comparable about size and nutritional status, measured as total body length and weight, respectively. The species B. bagre and G. barbus are probably similar regarding excretion metabolism because of physiological similarities since both belong to the Ariidae fish family. The biomass ingested of each prey species was not estimated to compare possible quantitative differences between the consumers (Tavares \& Di Beneditto 2017), but differences in feeding assimilation were recorded in the present study (X. kroyeri was the most important to B. bagre, while $P$. porosissimus to G. barbus). The mean $\delta^{15} \mathrm{~N}$ value of $X$. kroyeri is higher than P. porosissimus, as showed in Figure 2, and it is reflecting in the nitrogen isotope value of the consumers. It is worth to say that the catfishes' $\delta^{15} \mathrm{~N}$ values did not represent differences in their trophic positions, but differences in their prey isotopic values. The interpretation 


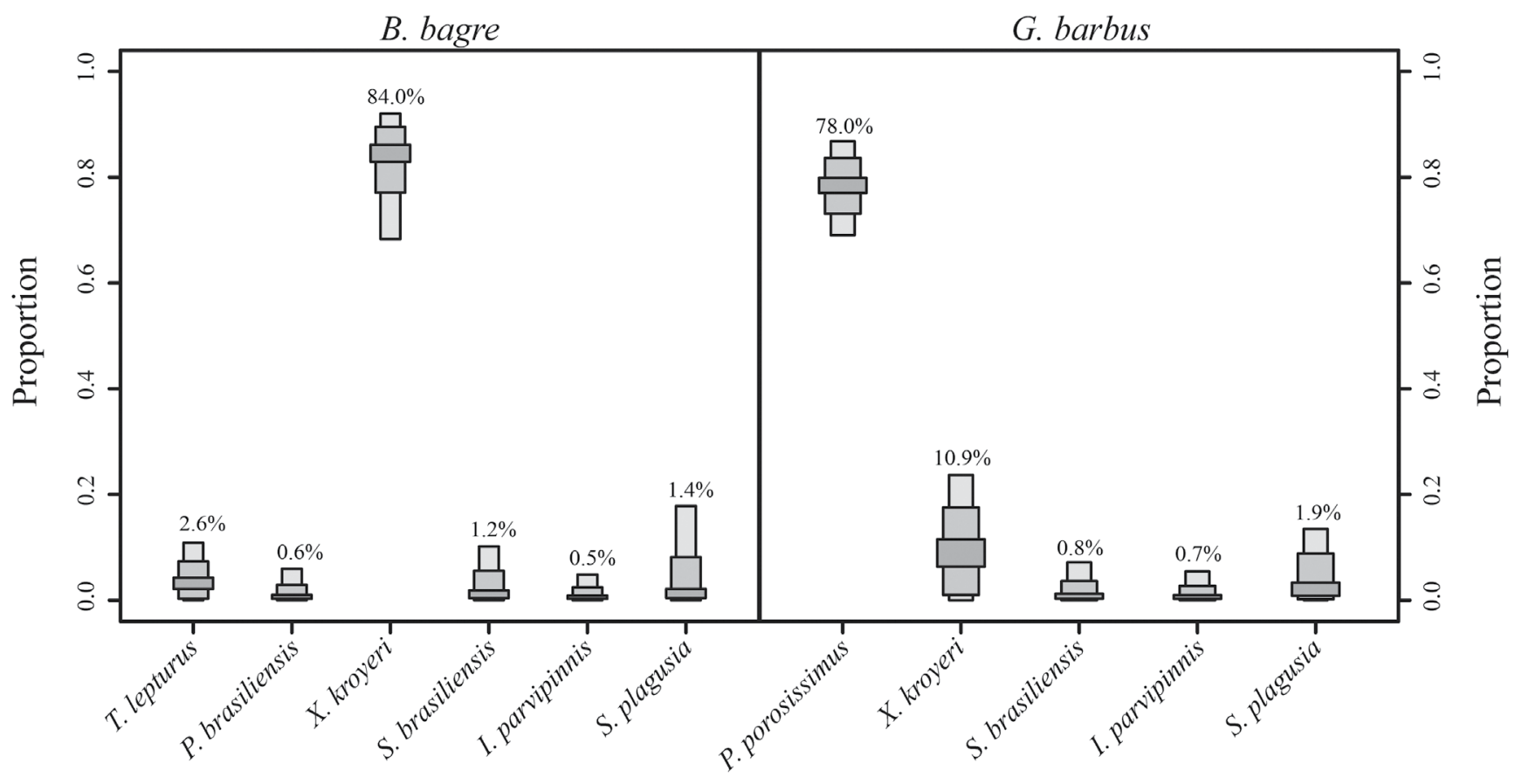

Figure 3. Results of SIAR (Stable Isotope Analysis in R) showing 95,75 and $25 \%$ credibility intervals of prey species contributions to the diet of the catfishes Bagre bagre and Genidens barbus in northern Rio de Janeiro State, south-eastern Brazil. The mean contribution values (\%) for each prey species are showed above the credibility intervals.

Table 1. Quantitative niche metrics of the catfishes Bagre bagre and Genidens barbus in northern Rio de Janeiro State, south-eastern Brazil. NR= $\delta^{15} \mathrm{~N}$ range, $\mathrm{CR}=$ $\delta^{13} \mathrm{C}, \mathrm{CD}=$ distance to centroid, $\mathrm{SDNND}=$ standard deviation of nearest neighbour distances, $\mathrm{SEA}=$ standard ellipse area, $\mathrm{LQ}=$ lower quartile and $\mathrm{UQ}=$ upper quartile .

\begin{tabular}{lcccccc}
\hline & NR & CR & CD & SDNND & \multicolumn{2}{c}{$\begin{array}{c}\left.\text { SEA (\%o }{ }^{2}\right) \\
\text { Median }\end{array}$} \\
\hline Bagre bagre & 1.3 & 0.6 & 0.36 & 0.07 & 0.15 & 0.17 \\
Genidens barbus & 1.1 & 0.7 & 0.42 & 0.02 & 0.22 & 0.26 \\
\hline
\end{tabular}

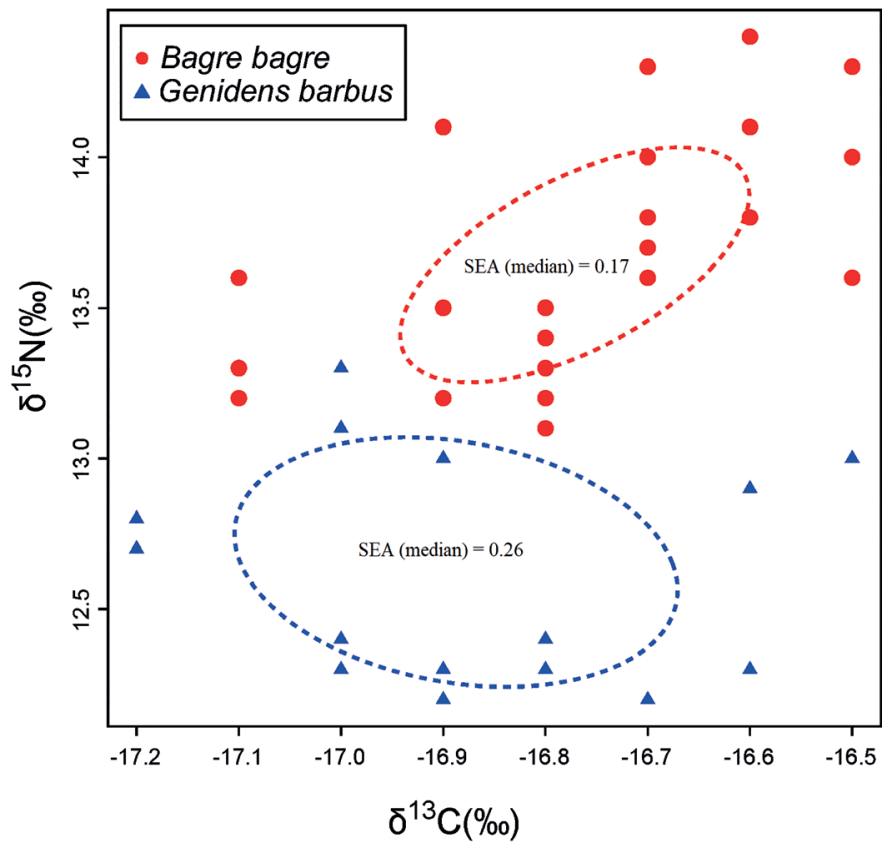

Figure 4. Stable isotope values of the catfishes Bagre bagre and Genidens barbus in northern Rio de Janeiro State, south-eastern Brazil. Lines depict the standard ellipse (the $40 \%$ confidence interval) for the isotopic niches. of consumers' isotopic values without taking into account other food chain or web components can lead to misunderstandings about the species trophic role and/or their relationships in an ecosystem.

The second assumption that the isotopic niche of the consumers reflects their feeding preferences and assimilation was partially confirmed. The quantitative niche metrics indicated that specific differences are negligible regarding NR, CR and CD; however, SDNND and SEA were different between the species. The NR $\left(\delta^{15} \mathrm{~N}\right.$ range) pointed to comparable carnivore levels between the two species and the $\mathrm{CR}\left(\delta^{13} \mathrm{C}\right.$ range) indicated no difference in basal resources, with food web maintained mainly by bottom-associated resources. The metric $\mathrm{CD}$ (trophic diversity) revealed that these species are similar in terms of trophic function in the ecosystem (Layman et al. 2007). Although the SDNND values were low for B. bagre and G. barbus, indicating population trophic evenness for both species, the comparison showed a more even distribution of $G$. barbus in the trophic niche space. The trophic evenness reveals a more homogeneous feeding strategy among individuals from a population, which might minimise the interspecific competition. In turn, the possible increase of intraspecific competition in a homogeneous feeding strategy is compensated by ontogenetic differences in the diet, as widely reported in the literature for marine catfishes (e.g., Yanez-Arancibia \& Lara-Dominguez 1988, 
Mendonza-Carranza 2003, Mendonza-Carranza \& Vieira 2009, Denadai et al. 2012). The larger SEA for G. barbus indicates a greater niche width in comparison with $B$. bagre, probably reflecting a greater use of the available food resources.

The comparison between the isotopic niche width of the adult specimens of B. bagre and G. barbus showed to what extent they are sharing or segregating feeding resources in a marine coastal area. The sampling included only adult specimens captured by coastal fisheries practised in the same space-time period, revealing fish specimens in the same ontogenetic phase sharing the habitat locally. The absence of niche overlaps together with the populations trophic evenness point to a reduced feeding overlap between these catfish species. Further analysis that include spatial, seasonal and ontogenetic differences regarding the feeding habits of $B$. bagre and G. barbus should be done for a more comprehensive understanding about their trophic relationships in northern Rio de Janeiro State, south-eastern Brazil.

\section{Acknowledgments}

We are indebted to Dr. Marcelo Gomes de Almeida (UENF, Brazil) for conducting stable isotope analysis and to Silvana Ribeiro Gomes for helping with sampling. This study was funded by Conselho Nacional de Desenvolvimento Científico e Tecnológico - $\mathrm{CNPq}$ (grant $\mathrm{n}^{\circ}$ 301.259/2017-8) and Fundação Carlos Chagas Filho de Amparo à Pesquisa do Estado do Rio de Janeiro - FAPERJ (grant $\mathrm{n}^{\mathrm{o}}$ E-26/201.161/2014 and E-26/202.770/2017). MTM Tavares received undergraduate fellowship from CNPq.

\section{Author Contributions}

Ana Paula Madeira Di Beneditto: contributed in the concept and design of the study, data analysis and interpretation and in the manuscript preparation.

Maria Thereza Manhães Tavares: contributed to data collection and in the early stage of data analysis and interpretation.

Leandro Rabello Monteiro: contributed in data analysis and interpretation.

\section{Conflicts of Interest}

The authors declare that they have no conflict of interest related to the publication of this manuscript.

\section{References}

ARAÚJO, F.G. 1984. Hábitos alimentares de três bagres marinhos (Ariidae) no estuário da Lagoa dos Patos (RS), Brasil. Atlântica 7:47-63.

CAPELLI, R., DAS, K., DE PELLEGRINI, R., DRAVA, G., LEPOINT, G., MIGLIO, C., MINGANTI, V. \& POGGI, R. 2008. Distribution of trace elements in organs of six species of cetaceans from the Ligurian Sea (Mediterranean), and the relationship with stable carbon and nitrogen ratios. Sci. Total. Environ. 390:569-578.

CAUT, S., ANGULO, E. \& COURCHAMP, F. 2009. Variation in discrimination factors $\left(\wedge{ }^{15} \mathrm{~N}\right.$ and $\left.\wedge{ }^{13} \mathrm{C}\right)$ : the effect of diet isotopic values and applications for diet reconstruction. J. Appl. Ecol. 46:443-453.

CHAVES, P.T.C. \& VENDEL, A.L. 1996. Aspectos da alimentação de Genidens genidens (Valenciennes) (Siluriformes, Ariidae) na Baía de Guaratuba, Paraná. Rev. Bras. Zool. 13:669-675.
CHEREL, Y., HOBSON, K.A., BAILLEU, F. \& GROSCOLA, R. 2005. Nutrition, physiology, and stable isotopes: new information from fasting and molting penguins. Ecology 86:2881-2888.

DAS, K., LEPOINT, G., LEROY, Y. \& BOUQUEGNEAU, J.M. 2003. Marine mammals from the southern North Sea: feeding ecology data from $\delta 13 \mathrm{C}$ and $\delta 15 \mathrm{~N}$ measurements. Mar. Ecol. Prog. Ser. 263:287-298.

DEGANI, G. \& REVACH, A. 1991. Digestive capabilities of three commensal fish species: carp, Cyprinus carpio L., Oreochromis aureus x O. niloticus, and African catfish, Clarias gariepinus (Bruchell 1822). Aquac. Res. 22(4):397-403

DENADAI, M.R., BESSA, E., SANTOS, F.B., FERNANDEZ, W.S., SANTOS, F.M.C., FEIJÓ, M.M., ARCURI, A.C.D. \& TURRA. 2012. A. Life history of three catfish species (Siluriformes: Ariidae) from southeastern Brazil. Biota Neotrop. 2012; 12. http://www.biotaneotropica.org.br/v12n4/en/ abstract?article+bn01912042012.

DI BENEDITTO, A.P.M. \& LIMA, N.R.W. 2003. Biometria de teleósteos da costa norte do Estado do Rio de Janeiro para estudos sobre piscivoria. Biotemas 16(1):135-144.

DI BENEDITTO, A.P.M. \& RAMOS, R.M.A. 2004. Biology of the boto-cinza dolphin (Sotalia fluviatilis) in south-eastern Brazil. J. Mar. Biol. Assoc. UK. 84:1245-1250.

DI BENEDITTO, A.P.M., RAMOS, R.M.A. \& LIMA, N.R.W. 2001. Os golfinhos: origem, classificação, captura acidental, hábito alimentar. 1 ed. Editora Cinco Continentes, Porto Alegre.

DI BENEDITTO, A.P.M., SICILIANO, S. \& MONTEIRO, L.R. 2017. Herbivory level and niche width of juvenile green turtles (Chelonia mydas) in a tropical coastal area: insights from stable isotopes. Mar. Biol. 164(13). doi: 164 $10.1007 / \mathrm{s} 00227-016-3044-2$

DI BENEDITTO, A.P.M., SOUZA, C.M.M., KEHRIG, H.A. \& REZENDE, C.E. 2011. Use of multiple tools to assess the feeding preference of coastal dolphins. Mar. Biol. 158:2209-2217.

DIOGO, R. 2004. Morphological evolution, adaptations, homoplasies, constraints, and evolutionary trends: catfishes as a case study on general phylogeny and macroevolution. 1ed. Science Publishers, Enfield.

FERNANDES, L.P., SILVA, A.C., JARDIM, L.P., KEUNECKE, K.A. \& DI BENEDITTO, A.P.M. 2011. Growth and recruitment of the Atlantic seabob shrimp, Xiphopenaeus kroyeri (Heller, 1862) (Decapoda, Penaeidae), on the coast of Rio de Janeiro, southeastern Brazil. Crustaceana. 84:1465-1480.

FERNANDES, L.P., KEUNECKE, K.A. \& DI BENEDITTO, A.P.M. 2014. Produção e socioeconomia da pesca do camarão sete-barbas no norte do estado do Rio de Janeiro. Bol. Inst. Pesca 40:541-555.

FERRARIS Jr CJ. 2007. Checklist of catfishes, recent and fossil (Osteichthyes: Siluriformes), and catalogue of siluriform primary types. Zootaxa. 1418:1628.

FROESE, R. \& PAULY, D. FishBase. http://www.fishbase.org. 2018; Accessed in 22 January 2018.

FRY, B. 2008. Stable Isotope Ecology. 1 ed. Springer Science Business Media, New York.

GOMES, M.P., CUNHA, M.S. \& ZALMON, I.R. 2003. Spatial and temporal variations of diurnal ichthyofauna on surf-zone of São Francisco do Itabapoana beaches, Rio de Janeiro State, Brazil. Braz. Arch. Biol. Techn. 46:653-664.

HOBSON, K.A., SCHELL, D., RENOUF, D. \& NOSEWORTHY, E. 1996. Stable-carbon and nitrogen isotopic fractionation between diet and tissues of captive seals: implications for dietary reconstructions involving marine mammals. Can. J. Fish. Aquat. Sci. 53:528-533.

HOBSON, K.A. \& WELCH, H.E. 1992. Determination of trophic relationships within a high Arctic food web using $\delta 13 \mathrm{C}$ and $\delta 15 \mathrm{~N}$ analysis. Mar. Ecol. Prog. Ser. 84:9-18.

HURLBERT, S.H. \& LOMBARDI, C.M. Final collapse of the Neyman-Pearson decision theoretic framework and rise of the neoFisherian. Ann. Zool. Fenn. 36:311-349.

JACKSON, A.L., INGER, R., PARNELL, A.C. \& BEARHOP, S. 2011. Comparing isotopic niche widths among and within communities: SIBER - Stable Isotope Bayesian Ellipses in R. J. Anim. Ecol. 80:595-602. 
JENNINGS, S., PINNEGAR, J.K., NICHOLAS, V.C. \& WARR K.J. 2002 Linking size-based and trophic analyses of benthic community structure. Mar. Ecol. Prog. Ser. 226:77-85.

KRISHNAN, A.A., YOUSUF, K.S., KUMARAN, P.L., HARISH, N., ANOOP, B., AFSAL, V.V., RAJAGOPALAN, M., VIVEKANANDAN, E., KRISHNAKUMAR, P.K. \& JAYASANKAR, P. 2008. Stomach contents of cetaceans incidentally caught along Mangalore and Chennai coasts of India. Estuar. Coast. Shelf Sci. 76:909-913.

KURLE, C.M. \& WORTHY, G.A.J. 2001. Stable isotope assessment of temporal and geographic differences in feeding ecology of northern fur seals (Callorhinus ursinus) and their prey Oecologia. 126:254-265.

LAYMAN, C.A., ARRINGTON, D.A., MONTAN, C.G. \& POST, D.M. Can stable isotope ratios provide for community-wide measures of trophic structure? Ecology. 2007; 88:42-48.

MARCENIUK, A.P. 2005. Chave para identificação das espécies de bagres marinhos (Siluruformes, Ariidae) da costa brasileira. Bol. Inst. Pesca. 31:89-101.

MARCENIUK, A.P., BETANCUR, R., GIARRIZZO, T., FREDOU, F.L. \& KNUDSEN, S. 2015. Bagre bagre. The IUCN Red List of Threatened Species 2015. http://dx.doi.org/10.2305/IUCN.UK.2015-2.RLTS. T190228A1945010.en. Accessed 14 April 2017.

MENDONZA-CARRANZA, M. 2003. The feeding habits of gafftopsail catfish Bagre marinus (Ariidae) in Paraiso coast, Tabasco, Mexico. Hidrobiológica. 13:119-126.

MENDONZA-CARRANZA, M. \& VIEIRA, J.P. 2009. Ontogenetic niche feeding partitioning in juvenile of white sea catfish Genidens barbus in estuarine environments, Southern Brazil. J. Mar. Biol. Assoc. of UK. 98:839-848.

MISHIMA, M. \& TANJI, S. 1982. Nicho alimentar de bagres marinhos (Teleostei; Ariidae) no complexo estuarino lagunar da Cananéia $\left(25^{\circ} \mathrm{S}\right.$, $\left.48^{\circ} \mathrm{W}\right)$. Bol. Inst. Pesca. 9:131-140.

NAVARRO, J., SÁEZ-LIANTE, R., ALBO-PUIGSERVER, M., COLL, M. \& PALOMERA, I. 2017. Feeding strategies and ecological roles of three predatory pelagic fish in the western Mediterranean Sea. Deep-Sea Res. II. 140:9-17.

NEWSOME, S.D., DEL RIO, C.M., BEARHOP, S. \& PHILLIPS, D.L. 2007. A niche or isotopic ecology. Front. Ecol. Environ. 5:429-436.

PARNELL, A.C., INGER, R., BEARHOP, S. \& JACKSON, A.L. 2010. Source partitioning using stable isotopes: coping with too much variation. PlosOne. 5:e9672. doi:10.1371/journal.pone.0009672
PARNELL, A. \& JACKSON, A. 2013. SIAR: Stable Isotope Analysis in R. R package version 4.2.2. https://CRAN.R-project.org/package=siar.

PETERSON, B.J. \& FRY, B. 1987. Stable isotopes in ecosystem studies. Annu. Rev. Ecol. Sys. 18:293-320.

PEREIRA, R., VALENTE, L.M.P., SOUSA-PINTO, I. \& REMA, P. 2012. Apparent nutrient digestibility of seaweeds by rainbow trout (Oncorhyncus mykiss) and Nile tilapia (Oreochromis niloticus). Algal Res. 1:77-82.

PHILLIPS, D.L., INGER, R., BEARHOP, S., JACKSON, A.L., MOORE, J.W., PARNELL, A.C., SEMMENS, B.X. \& WARD, E.J. 2014. Best practices for use of stable isotope mixing models in food-web studies. Can. J. Zool. 92:823-835.

PIERCE, G.J. \& BOYLE, PR.. 1991. A review of methods for diet analysis in piscivorous marine mammals. Oceanogr. Mar. Biol. Annu. Rev. 29:409-486

POST, D.M., LAYMAN, C.A., ARRINGTON, D.A., TAKIMOTO, G., QUATTROCHI, J. \& MONTAÑA, C.G. 2007. Getting to the fat of the matter: models, methods and assumptions for dealing with lipids in stable isotope analyses. Oecologia. 152:179-189.

R DEVELOPMENT CORE TEAM. 2016. R: A Language and Environment for Statistical Computing. Version 3.3.1. R Foundation for Statistical Computing.

SANTOS, M.C.O., ROSSO, S., SANTOS, R.A., LUCATO, S.H.B. \& BASSOI, M. 2002. Insights on small cetacean feeding habits in southeastern Brazil. Aquat Mamm 28:38-45.

SILVA, W.C., MARCENIUK, A.P., SALES, J.B.L. \& ARARIPE, J. 2016. Early Pleistocene lineages of Bagre bagre (Linnaeus, 1766) (Siluriformes: Ariidae), from the Atlantic coast of South America, with insights into demography and biogeography of the species. Neotrop. Ichthyol. 14:e150184.

TAVARES, M.T.M. \& DI BENEDITTO, A.P.M. 2017. Feeding habits and behaviour of Bagre bagre and Genidens barbus, two ariid catfishes (Pisces: Silutiformes) from Southeastern Brazil. J. Threat. Taxa. 9(10):10771-10775.

VELASCO, G., REIS, E.G. \& VIEIRA, J.P. 2007. Calculating growth parameters of Genidens barbus (Siluriformes, Ariidae) using length composition and age data. J. Appl. Ichthyol. 23:64-69.

YÁNEZ-ARANCIBIA, A. \& LARA-DOMÍNGUEZ, A.L. 1988. Ecology of three sea catfishes (Ariidae) in a tropical coastal ecosystem - Southern Gulf of Mexico. Mar. Ecol. Prog. Ser. 49:215-230.
Received: 08/02/2018

Revised: $11 / 04 / 2018$

Accepted: 15/04/2018

Published online: 10/05/2018 